\title{
對인도네시아 무상원조
}

\section{I. 핵심내용}

1. 주인도네시아 대사관은 빙인도네시아 무상원조 현황 및 평가라는 주제로 관계직원 등을 대상으로 자체 세미나를 개최함.

2. KOICA의 중점지원 대상국으로서 인도네시아에 대한 지원이 15 년 경과한 현 시점에서 그동안 실시된 사업을 평가하고 향후 발전적인 사업추진 방향 정립 을 위해 국별 검토가 필요하다고 판단되는 바, 본부 의 국별 원조평가 계획 수립시 인도네시아를 반드시 포함하여 주실 것을 건의함.

\section{II. 상세내용 - 對인도네시아 무상원조 현황 및 평가 ${ }^{11}$}

1. 한국의 공적개발원조(ODA) 현황

1) $\mathrm{ODA}$ 의 종류

\section{가. 양자간 원조}

무ㅅㅏㅏㅇ원조

ㅁ 유상원조(EDCF)

\section{나. 다자간 원조}

ㅁ국제기구 분담금, 출연 및 출자

ㅁ 국제기구에 대한 양허성 융자 
2) 우리나라의 연도별 ODA

(단위: 백만불)

\begin{tabular}{l|c|c|c|c}
\hline \multicolumn{1}{|c|}{ 구분 } & '00 & '01 & '02 & '03 \\
\hline ODA 총계 & 212.07 & 264.65 & 278.78 & 365.91 \\
양자간 원조 & 131.19 & 171.54 & 206.76 & 245.17 \\
-무상원조 & 47.78 & 52.97 & 66.70 & 145.46 \\
-유상원조(EDCF) & 83.41 & 118.57 & 140.06 & 99.71 \\
다자간 원조 & 80.89 & 93.11 & 72.02 & 120.74 \\
ODA/GNI 비율(\%) & 0.047 & 0.063 & 0.060 & 0.060 \\
\hline
\end{tabular}

3) 주요 국가 ODA 순위(2004)

뮤모별 : 미국(190억불), 일본(89억불), 프랑스(85 억불), 영국(78억불), 독일(75억불)

ODA/GNI 비율 : 노르웨이(0.87\%), 룩셈부르크 (0.85\%), 덴마크(0.84\%), 네덜란드(0.74\%)

※미국(0.16\%), 일본(0.19\%), OECD DAC 평균 $(0.25 \%)$

\section{2. 한국의 무상원조}

1) 연도별 추이

(단위: 억원/백만불)

\begin{tabular}{c|c|c}
\hline 연도/구분 & 총계(백만불) & 증가율(\%) \\
\hline '91 & $184(22)$ & - \\
'93 & $265(33)$ & 14.7 \\
'95 & $383(48)$ & 20.4 \\
'97 & $607(76)$ & 30.3 \\
'99 & $471(36)$ & $\triangle 22.5$ \\
'01 & $729(66)$ & 39.7 \\
'02 & $861(66)$ & 18.1 \\
'03 & $1,678(140)$ & 94.9 \\
'04 & $2,224(185)$ & 32.5 \\
'05 & $1,676(146)$ & $\triangle 24.6$ \\
\hline
\end{tabular}

\section{2) 2005년 사업계획}

ㅁ 127 개 국가 및 6 개 국제(지역)기구에 1,578 억원 지 원 계획

\begin{tabular}{|c|c|c|c|}
\hline 구분 & 국가수 & 예산 & 점유율 \\
\hline 총계 & 127국 6기구 & $1,578(370)$ & $100 \%$ \\
\hline 아·태 & 25국 & $554(48)$ & $35.1 \%$ \\
\hline 미주 & 31국 & $93(8)$ & $5.9 \%$ \\
\hline 동구·CIS & 19국 & $81(7)$ & $2.2 \%$ \\
\hline 중동 & $11 ㄱ ㅜ ㄱ ~$ & $5,994(52)$ & $38 \%$ \\
\hline 아프리카 & $41 ㄱ ㅜ ㄱ ~$ & $97(8)$ & $3.2 \%$ \\
\hline 국제기구 & 6기구 & $5(0.49)$ & $0.3 \%$ \\
\hline 미배정 & - & $146(12)$ & $9.3 \%$ \\
\hline
\end{tabular}

\section{3) 상위 수원국}

\begin{tabular}{c|c|c|c}
\hline \multirow{2}{*}{ 순위 } & \multicolumn{3}{|c}{2004 년 } \\
\cline { 2 - 4 } & 국명 & 지원액(천불) & 점유율(\%) \\
\hline 1 & 이라크 & 59,523 & 33.5 \\
2 & 아프가니스탄 & 17,378 & 9.8 \\
3 & 베트남 & 9,851 & 5.5 \\
4 & 인도네시아 & 6,565 & 3.7 \\
5 & 필리핀 & 6,406 & 3.6 \\
\hline \hline \multirow{2}{*}{ 순위 } & \multicolumn{3}{|c}{ 2005년 } \\
\cline { 2 - 4 } & 국명 & 지원액(천불) & 점유율(\%) \\
\hline \multirow{2}{*}{1} & 이라크 & 50,000 & 36.4 \\
2 & 베트남 & 8,406 & 6.1 \\
3 & 인도네시아 & 5,338 & 3.9 \\
4 & 스리랑카 & 4,750 & 3.5 \\
5 & 캄보디아 & 4,059 & 3.0 \\
\hline
\end{tabular}

\section{3. 인도네시아 지원 실적 및 평가}

\section{1) 인도네시아 지원 실적}

\section{가. 지원금액(1991 2004년)}

미닌ㄴ 14 년간 對인니 무상원조는 총 2,865 만불을 기록하여 KOICA 지원 130 여개 개도국 중 지원규 모면에서 4 위를 차지 
ㅁ 지원형태별로는 연수생초청 1,223 명, 전문가 26

명, 태권도사범 1 명, 봉사단원 203 명, 개발조사 10 건 624만불, 프로젝트 8건 853만불 등

(단위: 천불)

\begin{tabular}{c|c|c}
\hline 연도 & 금액 & 순위 \\
\hline '91 & 331 & $7 / 120$ \\
'93 & $1,143$. & $2 / 133$ \\
'95 & 1,232 & $3 / 139$ \\
'96 & 1,690 & $4 / 140$ \\
'98 & 1,526 & $3 / 126$ \\
'00 & 1,984 & $4 / 133$ \\
'01 & 1,939 & $6 / 138$ \\
'02 & 2,770 & $3 / 141$ \\
'03 & 2,613 & $6 / 130$ \\
'04 & 6,565 & $4 / 138$ \\
\hline
\end{tabular}

\section{나. 사업유형별 지원 비율(1991 2004년 총액기준)}

므포젝트, 봉사단파견, 개발조사, 연수생초청을 위주로 실시

\begin{tabular}{c|c|c|c}
\multicolumn{3}{|c}{} & (단위·천불/명,건) \\
\hline \hline 구분 & 금액(인원,건수) & 비율(\%) & 지원 순위 \\
\hline 프로젝트사업 & $8,529(8)$ & 29.8 & 1 \\
봉사단파견사업 & $6,255(203)$ & 21.9 & 2 \\
개발조사사업 & $6,236(10)$ & 21.8 & 3 \\
연수생초청사업 & $5,024(1,223)$ & 17.5 & 4 \\
전문인력파견사업 & $1,663(26)$ & 5.7 & 5 \\
물자지원사업 & $944(17)$ & 3.3 & 6 \\
NGO사업 & $23(1)$ & 0.1 & 7 \\
계 & 28,650 & 100.0 & \\
\hline
\end{tabular}

\section{2) 사업별 지원효과 평가}

\section{가. 연수생초청사업}

ㅁ 1991 2004년까지 경제, 농수산, 과학, 기술 등 제 반 분야에서 1,223 명에 달하는 주재국 공무원 및 연구 · 기술 인력을 한국에 초청

ㅁ방한 연수생들은 한국의 경제개발 경험, 최고수준
의 IT산업, 새마을운동을 통한 빈곤퇴치 및 소득 증대, 최근 $\mathrm{IMF}$ 위기 극복 등에 대한 연수과정에 대해 많은 관심 표명

- 인니 중견 간부급 이상 공무원과 각계 전문가들 의 참여로 친한 감정 확산 및 각 분야에서의 협 력관계 조성에 기여

- 우리의 산업기술과 수출상품에 대한 호감도와 이해를 제고하므로써 양국간 경제협력 강화에 긍정적 효과 기대

\section{나. 해외봉사단원파견사업}

ㅁ 1990년 최초 파견된 이후 2004년까지 총 203명이 파견

- 2005년 7월말 현재 86명(남자 51명, 여자 35명) 이 활동 중

- 파견분야별로는 한국어교육, 컴퓨터교육, 농수 산분야, 지역사회개발 등으로 구성

- 2004년부터 팀제봉사단 파견 착수

ㅁㅡㅡㄱㅎㅣ 2004년부터는 파견단원이 대폭 확대되었으 며 예년의 20 여명 선에서 2005년 말까지는 100 여 명으로 전망됨.

- 노무현 대통령은 '발리 $\mathrm{ASEAN}+3$ 정상회의 (2003년 10월) 시 봉사단원 대폭 확대파견 계획 발표(연 220명 $\rightarrow 720$ 명)

면지인들의 봉사단원들에 대한 인식과 평가가 매 우 호의적

- 인니 정부는 물론 일반 국민들에게 우리나라에 대한 우호적인 인식을 심는데 크게 기여

- 인니전역에 산재되어 Grass-root 계층의 주민 
들과 함께 생활하면서 기술전수 및 소득증대 향 상을 지원함으로써 현지 친화적인 원조수단으로 평가됨.

ㅁ봉사활동을 마친 $\mathrm{OB}$ 봉사단원 중 약 10 명 정도가 현지에 정착 또는 국내 기업 파견근무로 활동 중

\section{다. 전문가파견사업}

ㅁ총 26 명의 우리나라 전문가를 파견하여 인니의 경 제 - 사회 발전과 인적자원개발 노력에 우리의 개 발경험과 신기술을 전수, 지도

므동안 한-인니간 협력필요 분야인 자원개발분 야, 농수산분야, 환경분야, 직업훈련분야 등에 전 문가를 파견

- 주재국의 개발노력에 도움을 주는 한편, 우리나 라에 필요한 對인니 분야별 정보축적과 경제협 력 기반확대에 기여

\section{라. 태권도사범파견사업}

ㅁ 1991년부터 파견되어 우리의 전통문화 보급을 통 한 친한인사 확보 및 한류열풍 조성에 크게 기여 ㅁ태권도 국가대표팀을 지도하여 각종 국제대회에 서 입상시킴으로써 인니 태권도를 국제적인 수준 으로 향상시킴.

- 2003년에는 파리 세계태권도선수권대회 금메달 1 개, 호치민 동아시아게임 금메달 2 개를 획득

- 금년 4월 사우디에서 개최된 아랍권 체육축전에 서 금메달 1 개, 동 메달 1 개 획득

- 지방 순회활동을 통한 지방태권도협회 결성 지 원, 현지인 태권도 지도자 육성, 전국 태권도대
회 개최 지원 등의 다각적인 노력으로 1990 년대 초 3 만 명에 불과하던 인니 태권도 인구를 현재 60 만 명선으로 증가시키는데 크게 기여

\section{마. 개발조사사업}

ㅁ우리나라가 국제적으로 비교 우위를 지니고 있고 우리 기업의 인니 진출기반 조성에 기여할 수 있는 전력, 도로, 주택개발 등의 사회인프라 분야에 중 점을 두고 지원

ㅁ 광물자원, 농업 및 산림분야에 지원된 개발조사사 업은 해외 자원 의존도가 높은 우리나라가 주재국 에 대한 관련자료 및 정보를 확보하고 인니 정부와 긴밀한 자원협력관계를 확대에 기여함.

\section{바. 프로젝트사업}

ㅁㅡㅡ로젝트사업은 농업개발분야, IT분야, 직업훈련 분야에 주로 지원

ㅁ직업훈련분야 프로젝트

- 인니직업훈련원 지원사업('85 '94/520만불)과 이동식 직업 훈련사업('94 '95)으로 우리나라의 직업훈련기술 전수를 통해 인도네시아 내 한국 형 직업훈련 기술 및 제도발전에 기여

- 동 훈련원에서 교육받은 훈련교사들이 인니 소 재 많은 직업훈련원에 근무, 기능 인력개발에 대 한 기여도와 파급효과가 있었던 것으로 평가

ㅁ 농업개발분야 프로젝트

- 남부 깔리만탄지역 저습지 벼농사기계화 지원사 업('98 '01/110만불)을 지원 완료한데 이어, 건 기 농업개발을 위해 밭작물 농업 중점개발지원 
사업('02 '04/70만불)을 지원

- 저습지 벼농사 농기계화 지원사업은 식량증산에 대한 인니정부의 개발 정책에 부응, 해당지역 농 민들에게는 농가소득 증대에 기여하는 한편, 인 니 정부의 농기계화 정책 결정자들에게도 영향 을 미쳐 남부 슬라웨시 주정부의 기계화사업에 국산 경운기를 수출하는 효과 거양

ㅁ IT분야 프로젝트

- 2000년 11월 한-인니 정상회담시 우리 대통령 지원 약속으로 250 만불 규모로 2 개의 프로젝트 를 지원

• 인도네시아대학 IT센터 설립지원사업('01 '03/125 만불)

• 중소기업발전센터 IT인프라구축 지원'01 '04/125 만불)

- IT산업 인프라 및 인적자원 개발 부족으로 인한 선진국과의 Digital Divide의 해소에 기여할 뿐만 아니라 세계적 수준인 우리 IT산업의 인니 진출 및 수출증대에도 크게 도움이 될 것으로 기대됨. ㅁ한-인니 친선 스포츠교류센터 지원사업

- 주재국 스포츠 발전과 특히 태권도 보급, 홍보를 위해 지원된 동 사업은 2005 년 3 월 13 일 완공되 어 청소년체육부에 기증되었으며 냉방시설이 완 비된 다목적 체육관으로 주재국의 열악한 스포 츠 환경을 감안할 경우, 매우 우수한 시설로 한 국의 지원을 상징하는 기념물로 자리잡을 것으 로 기대됨.

\section{2005년도 사업추진 현황}

\section{1) 2005년 사업 계획}

533.8만불 지원계획(지원대상 127 개도국/6기구 중 3 위)

- 연수생초청 41 개 과정 84 명, 전문가파견 6명, 태 권도사범파견 1명, 봉사단파견 120 명(신규 45 명), 개발조사 3 건 18.2 만불, 프로젝트 2 건 112.9 만불 등

-2005년 8월 현재 KOICA 파견인력은 총 91명 (사무소 직원 4명, 봉사단 86 명, 태권도사범 1명) ㅁ사업별 지원 내역

\begin{tabular}{|c|c|c|}
\hline 사업명 & 지원규모 & 세부계획 \\
\hline 연수생초청 & 362천불 & 41과정 84명 \\
\hline 전문가파견 & 173천불 & $\begin{array}{l}\text { 대테러전문가 3명(1주일), 농기계 1명(1년), } \\
\text { 증권 인프라구축2명(3개월) }\end{array}$ \\
\hline 봉사단파견 & 2,263천불 & $\begin{array}{l}\text { 120명(신규 45, 기존 } 75 \text { 명) } \\
\text {-신규 45명 : 팀제, 일반, 협력요원 등 }\end{array}$ \\
\hline 태권도사범파견 & 91천불 & $\begin{array}{l}\text { 태권도사범 지속 파견 } \\
\text {-오일남/청소년 체육부 }\end{array}$ \\
\hline 개발조사 & 3건/182천불 & $\begin{array}{l}\text { - 일본뇌염 예방 및 퇴치 백신사업 } \\
\text { 96천불('02 '06/210천불) } \\
\text { - 카리안 다목적댐건설 F/S } \\
\text { 82천불('04 '06/1,700천불) } \\
\text { - 마나도 우회도로건설 F/S } \\
\text { 4천불('04 '05/500천불) }\end{array}$ \\
\hline 프로젝트 & 2건/1,129천불 & $\begin{array}{l}\text {-한-인니 친선 스포츠센터 건립사업 } \\
\text { 329천불('03 '05/2,800천불) } \\
\text { - 임목개량 및 현대식 양묘장건립사업 } \\
\text { 800천불('05 '07/1,600천불) }\end{array}$ \\
\hline 긴급재난 구호 & 1,100천불 & $\begin{array}{l}\text {-현금지원 400천불 } \\
\text {-긴급물품지원 } 700 \text { 천불 }\end{array}$ \\
\hline NGO지원 & 37천불 & $\begin{array}{l}\text { - 학교 보건프로그램을 통한 아동건강 증 } \\
\text { 진 사업(플랜 코리아) }\end{array}$ \\
\hline
\end{tabular}

2) 서남아시아 지진 · 해일 피해복구 특별지원사업

가. 우리 정부의 특별지원 내용(향후 3년 계획) 
ㅁ 아체지역 재건복구사업 : 1,500 만불

-현금지원 : 60 만불(지원 완료)

• 1차 20만불(2004. 12.30)

•2차 40만불(2005. 1. 17)

- 긴급 구호물자지원 : 70만불(1 3차 지원완료)

-1차 의약품, 분유 등 17종(2005. 1. 28/항공운송)

-2차 텐트, 담요 등 29종(2005. 2. 23/해상운송)

- 3차 물탱크트럭 등 3종(2005. 5. 17/해상운송)

- 잔여 1,370 만불 재건복구사업추진 계획

- 재건복구사업 패키지학교, 병원건립 사업 등 10 개 프로젝트사업) 인니측에 제안(2005. 3. 24)

- 인니측은 피해지역 '종합개발 마스터플랜' 작성 후 재건 · 복구 사업 추진계획

· 마스터플랜 완료(2005. 4. 16)

- 아체 - 니아스 재건복구특별가구(BRP) 설립(2005. 4. 30)

- 우리측 제시 사업 중 6 개 사업 선정 잠정합의 (2005. 7. 8)

· 학교 · 병원건립사업, 재건,복구 기자재제공, 연수생 초청, 망그로부 숲 복구사업, 어선 지원사업 등

\section{나. 니아스섬 지진피해복구 특별지원}

ㅁ현금지원 : 10만불(2005. 4. 8)

ㅁ물품지원 : 10 만불(텐트, 담요 등/2005. 5. 4)

[자료 : 주인도네시아 KOICA 사무소] 


\section{일본의 ODA}

\section{1. 일본 ODA 현황}

$$
\begin{aligned}
& \text { 口 총 ODA 금액 } \\
& \text { - 2002년 : 92.9억불 } \\
& \text { - 2003년 : 86.7억불 } \\
& \text { - 2004년 : 89억불 }
\end{aligned}
$$

※ JICA 주요사업 형태/실적

\begin{tabular}{c|c|c}
\hline 구분 & 2002년 & 2003년 \\
\hline 대상국가/지역 & 158 개국/지역 & 167 개국/지역 \\
연수생초청 & 15,466 명 & 16,277 명 \\
전문가파견 & 2,802 명 & 2,946 명 \\
개발조사팀파견(인원) & 8,505 명 & 7,753 명 \\
봉사단파견 & 1,234 명 & 1,310 명 \\
봉사단파견(Senior) & 529 명 & 539 명 \\
\hline
\end{tabular}

\section{2. 일본의 붱인니 지원 현황}

(단위: 백만불)

\begin{tabular}{c|c|c|c|c}
\hline 구분 & 2000년 & 2001년 & 2002년 & 2003년 \\
\hline Loan & 991.7 & 908.2 & 889.4 & 938.8 \\
Grant Aid & 74.5 & 72.6 & 72.9 & 82.6 \\
Technical Cooperation & 100.7 & 107.7 & 106 & 123.2 \\
계 & $1,166.9$ & $1,088.5$ & $1,068.3$ & $1,144.6$ \\
\hline
\end{tabular}

\section{3. 일본의 재건복구 지원사업 내용(5억불)}

1) 복구지원사업(단기) : 2005. 1 12

$\square$ 긴급의료지원

$\square$ 기본 인프라 재건

- 반다아체 및 물라보 공항 시설복구사업

- 피해지역 토지대장 복구사업

- 상하수도 복구 개발조사사업

- 북수마트라 해안도로 복구 개발조사사업 


\section{참고자료}

2) 재건지원사업(중기) : 2005. 3

$\square$ 재건복구 계획수립 지원

- Syah Kualaeogkr 재건복구 청사진작성 지원사업

- 아체개발 청년회의 지원사업

- 반다아체시 도시계획수립 개발조사사업

$-\mathrm{BRR}$ 지원사업

$\square$ 사회, 공공시설 향상 지원

- 기초교육 지원사업

- 재난지역 정신장애 치료를 위한 능력배양사업

$\square$ 지역사회 재건 지원

- Livelihood support(선박건조, 수산업, 농업, 가내공업 등)

- Post Trauma Syndrome Disease(PTSD) support

- 식수개발 및 공중위생 지원사업 등

$\square$ 지역경제 재건

- 중소기업 진흥 지원사업(지역특화산업 및 전통산업)

$\square$ 지방 공공행정 능력강화 및 분권화 이행 지원사업

- 지방공무원 교육훈련

- 지역 선거지원

3) 쓰나미 조기경보 및 재난관리 시스템 능력배양 및 제도개발사업(중장기)

$\square$ GIS maintenance, Mangrove project 등 